\title{
Dual effect of macroalgal extracts on growth of bacteria in Western Baltic Sea
}

\author{
Dualidad en el efecto de extractos macroalgales del mar Báltico occidental \\ sobre el crecimiento bacteriano
}

Franz Goecke $^{1}$, Antje Labes ${ }^{1}$, Jutta Wiese ${ }^{1}$ and Johannes F. Imhoff ${ }^{1}$

\author{
${ }^{1}$ Kieler Wirkstoff-Zentrum am GEOMAR, Helmholtz-Zentrum für Ozeanforschung, Am Kiel-Kanal 44, Kiel D-24106, \\ Germany. fgoecke@geomar.de
}

\begin{abstract}
Resumen. - Se asume que las características biológicas de las cepas bacterianas utilizadas para test de bioactividad tienen fuerte influencia sobre la suceptibilidad contra compuestos antibacterianos. Por lo tanto, la selección de bacterias para pruebas microbiológicas puede acelerar conclusiones respecto al efecto de extractos y metabolitos macroalgales sobre el crecimiento microbiano. Para probar tal presunción, se analizó la actividad biológica de extractos crudos de 16 macroalgas del fiordo de Kiel (Alemania). Los extractos macroalgales fueron probados frente a un set de 10 microorganismos que involucraron 5 cepas bacterianas de común uso en análisis estándar y 5 cepas de bacterias asociadas a macroalgas. Catorce macroalgas (88\%) presentaron actividad antibiótica contra al menos una cepa. Pese a la alta proporción de extractos activos, sólo 3 cepas estándar fueron susceptibles a ellos y la actividad antibiótica fue baja (menos de $80 \%$ de inhibición). La mayoría de los extractos inhibió a Bacillus subtilis, mientras que no hubo actividad inhibitoria frente a Erwinia amylovora, Escherichia coli y las cepas macroalga-asociadas. Por el contrario, la totalidad de extractos estimuló el crecimiento de al menos 2 cepas bacterianas. Mientras que la estimulación del crecimiento sobre las cepas de uso estándar fue rara (22,5\%) con la excepción del fitopatógeno Erwinia amylovora y 2 casos con Staphylococcus lentus, fue común frente a las bacterias asociadas a macroalgas (77,5\%), especialmente frente a Bacillus algicola, Pseudomonas marincola y los dos patógenos de algas. El presente estudio demostró que los extractos macroalgales pueden producir diferentes efectos tal como la inhibición o estimulación del crecimiento bacteriano, dependiendo del origen de las bacterias empleadas para los test, ya sea por el uso de un set de cepas estándar o provenientes del ambiente marino, respectivamente.
\end{abstract}

Palabras clave: Algas marinas, actividad antibacteriana, estimulación del crecimiento bacteriano, fiordo de Kiel

Abstract.- It is assumed that the biological characteristics of the bacterial strains used in bioactivity tests have strong influences on their susceptibility against antibacterial compounds. Therefore, the selection of bacterial test strains may rush conclusions on the effect of macroalgal extracts and metabolites on bacteria. To proof this assumption, we have analysed the biological activities of crude extracts of 16 macroalgae from the coastal waters of Kiel Fjord (Germany), and tested their effect against a panel of 10 microorganisms comprising 5 standard test strains of bacteria and 5 macroalga-associated bacteria. Fourteen macroalgae (88\%) displayed antibacterial activity against at least one of the test strains. Despite the high proportion of extracts exhibiting antimicrobial activity, only 3 strains of the standard set were susceptible to macroalgal extracts and the overall activities were low (less than $80 \%$ of inhibition). Most of active extracts inhibited Bacillus subtilis, while no inhibition effects were found against Erwinia amylovora, Escherichia coli, and the macroalga-associated bacteria. In contrast, all extracts produced stimulatory growth effects of at least two of the tested bacteria. While growth stimulation of standard set of bacteria was rare $(22.5 \%$ of total tests) with exception of plant pathogen Erwinia amylovora and two cases of Staphylococcus lentus, it was common among bacteria associated with macroalgae (77.5\%), especially Bacillus algicola, Pseudomonas marincola and both algal-pathogenic bacteria. This study demonstrates that macroalgal extracts can display different effects, i.e., inhibition or stimulation of bacterial growth depending on the origin of the test strains, which are derived from a standard panel or from the marine environment, respectively.

Key words: Marine algae, antibacterial activities, stimulation of bacterial growth, Kiel fjord 


\section{INTRODUCTION}

Secondary metabolites mediate numerous biological interactions and play a particular important role in mediating host-microbe associations in the ocean (Lane et al. 2010). Recently, it has been addressed that chemical interactions regulate the bacteria-macroalga relationships and may cause specific associations (Goecke et al. 2010, Sneed \& Pohnert 2011a). Indeed, different species of marine macroalgae growing in the same habitat under the same environmental conditions support different bacterial communities (Lachnit et al. 2009, Nylund et al. 2010). The biological active compounds (both deterrents and attractants) produced by macroalgae as well as those from the associated bacteria may be involved in shaping these epiphytic bacterial communities (Egan et al. 2000, Lachnit et al. 2010).

Macroalgal chemistry is rich and diverse, spanning most natural product classes and including functional group characteristics found from no other source (Maschek \& Baker 2008). The antibacterial activity of different extracts of macroalgae from almost all groups has been described in many studies around the world (Sridhar \& Vidyavathi 1991, Hellio et al. 2000, Magallanes et al. 2003, Freile-Pelegrin \& Morales 2004, Engel et al. 2006, Lane et al. 2009, Muñoz-Ochoa et al. 2010). Although several metabolites with antimicrobial activities have been already characterized from macroalgae, results of different studies on antibacterial activities of crude extracts of one and the same species are equivocal: While some studies reported antibacterial activities others did not (Sandsdalen et al. 2003).

Biotic factors such as reproductive state, age of the thallus of the macroalgae, as well as abiotic factors such as seasonality and geographic location have influence on the bioactivity of macroalgal extracts (Hellio et al. 2004, Paul \& Puglisi 2004, Arunkumar et al. 2010). Furthermore there are discrepancies related to the different extraction procedures and to the target microorganisms used in the bioassays (Sridhar \& Vidyavathi 1991, Kanagasabhapathy et al. 2006). Unfortunately, assessments of the antibacterial activity exhibited by macroalgae in the natural products literature has focused on biomedicallyrelevant strains, using standard microbial strains from terrestrial origin or of medical relevance (Engel et al. 2006, Paul et al. 2006, Hughes \& Fenical 2011). Bacteria from the marine habitat were rarely included, although bioactivity against these would make possible to draw conclusions in regard to the ecological role of the substances in the macroalga-bacteria interactions
(Jormalainen \& Honkanen 2008). It is expected that macroalgae should produce antibacterial compounds against microbial pathogens and that commensal bacteria should be adapted to grow within the algal phycosphere and its metabolites. Hence, the selection of bacteria for a test panel should be relevant in order to evaluate the ecological effects of secondary metabolites due to different responses of the chosen bacteria.

In order to prove if a selection of ecologically relevant bacteria results in different responses in the bioactivity tests as compared to a standard set of bacteria, we studied the effect of extracts from different macroalgae of the Kiel Fjord, Germany, upon bacterial growth.

\section{Materials AND METHODS}

\section{SAMPLING OF THE MACROALGAE}

Samples of 16 species belonging to 11 families of marine macroalgae were taken from distinct sites in the Kiel Fjord, Western Baltic Sea, Germany $\left(54^{\circ} 25.5^{\prime} \mathrm{N}, 10^{\circ} 12^{\prime} \mathrm{E}\right)$ (Table 1). The macroalgae were collected between 1 to $6 \mathrm{~m}$ depth. Until processing within $3 \mathrm{~h}$ after collection, the samples were stored in the dark at ambient seawater temperature using coolers. In the laboratory, the macroalgae were manually cleaned from sand, epiphytes and animals, and rinsed with sterile and filtered Baltic Sea water to remove associated debris, planktonic and loosely attached microorganisms.

Part of the macroalgae was fixed in $4 \%$ formaldehyde for its taxonomic identification. Algae were identified by examination of their thallus architecture and special morphological characters: Fronds, branching, and reproductive structures (Pankow 1971, Maggs \& Hommersand 1993). For the filamentous macroalgae histological cuts were performed and observed by light microscopy. The names of the species were used according to Guiry \& Guiry (2011). Voucher specimen were deposited in the Herbarium of Museo Nacional de Historia Natural, Santiago, Chile (code SGO).

\section{MaCroalgal EXTRACT PREPARATION}

Ten grams of the macroalgae were extracted by immersing them with $200 \mathrm{ml}$ dichloromethane (DCM) at room temperature and shaking them by hand (modified method from Nylund et al. 2005). The extracts were centrifuged at $4000 \mathrm{rpm}$ for $10 \mathrm{~min}$ and filtered through Whatman 542 filter paper (Freile-Pelegrin \& Morales 2004). All extracts were concentrated separately under reduced pressure in 
Table 1. List of macroalgae sampled from the Kiel Fjord (Baltic Sea, Germany). Names according to Guiry \& Guiry (2011) / Lista de macroalgas del fiordo de Kiel (Mar Báltico, Alemania). Nombres según Guiry \& Guiry (2011)

\begin{tabular}{|c|c|c|c|c|}
\hline Macroalgal species & Order & Family & $\begin{array}{l}\text { Sampling site } \\
\text { at Kiel Fjord }\end{array}$ & $\begin{array}{l}\text { Sampling } \\
\text { date }\end{array}$ \\
\hline \multicolumn{5}{|l|}{ Chlorophyta } \\
\hline Chaetomorpha linum (Müller) Kützing, 1849 & Cladophorales & Cladophoraceae & Strande & 21.10 .2009 \\
\hline Cladophora rupestris (Linnaeus) Kützing, 1843 & Cladophorales & Cladophoraceae & Strande & 21.10 .2009 \\
\hline \multicolumn{5}{|l|}{ Heterokontophyta } \\
\hline Fucus serratus Linnaeus, 1753 & Fucales & Fucaceae & Stohl & 19.01.2010 \\
\hline Fucus vesiculosus Linnaeus, 1753 & Fucales & Fucaceae & Bülk & 14.07.2009 \\
\hline Halosiphon tomentosus (Lyngbye) Jaasund, 1957 & Tilopteridales & Halosiphonaceae & Falkenstein & 24.04 .2011 \\
\hline Saccharina latissima (Linnaeus) Lane et al., 2006 & Laminariales & Laminariaceae & Tonnenhof & 14.07.2009 \\
\hline \multicolumn{5}{|l|}{ Rhodophyta } \\
\hline Bonnemaisonia hamifera (tetrasporoph.) Hariot, 1891 & Bonnemaisoniales & Bonnemaisoniaceae & Falkenstein & 20.11.2010 \\
\hline Callithamnion corymbosum (Smith) Lyngbye, 1819 & Ceramiales & Callithamniaceae & Falkenstein & 20.11.2010 \\
\hline Ceramium tenuicorne (Kützing) Waern, 1952 & Ceramiales & Ceramiaceae & Strande & 24.04 .2011 \\
\hline Ceramium virgatum Roth, 1797 & Ceramiales & Ceramiaceae & Strande & 21.10 .2009 \\
\hline Dasya baillouviana (Gmelin) Montagne, 1841 & Ceramiales & Dasyaceae & Strande & 21.10 .2009 \\
\hline Delesseria sanguinea (Hudson) Lamouroux, 1813 & Ceramiales & Delesseriaceae & Strande & 14.07.2009 \\
\hline Dumontia contorta (Gmelin) Ruprecht, 1850 & Gigartinales & Dumontiaceae & Strande & 01.06 .2010 \\
\hline Polysiphonia elongata (Hudson) Sprengel, 1827 & Ceramiales & Rhodomelaceae & Strande & 21.10 .2009 \\
\hline Polysiphonia nigra (Hudson) Batters, 1902 & Ceramiales & Rhodomelaceae & Strande & 21.10 .2009 \\
\hline Rhodomela confervoides Hudson) Silva, 1952 & Ceramiales & Rhodomelaceae & Falkenstein & 20.11 .2010 \\
\hline
\end{tabular}

a Speedvac RVC2-33 (Christ, Germany) until completely dry, weighed and kept at $+4^{\circ} \mathrm{C}$. For further tests, $1 \mathrm{mg}$ of the solid residue was resuspended in $1 \mathrm{ml}$ methanol.

\section{Antimicrobial testing}

The antimicrobial activity of crude extracts of macroalgae was tested against a panel of ten microorganisms comprising standard test strains and macroalgaassociated bacteria. The following microorganisms and nutrient media were used:

(i) Five microorganisms usually tested in standard laboratory tests of antibiotic activity (hereafter 'standard set'): Erwinia amylovora DSM 50901 (nutrient medium $\mathrm{M} 1=5 \mathrm{~g} \mathrm{l}^{-1}$ peptone, $3 \mathrm{~g} \mathrm{l}^{-1}$ meat extract in distilled water, pH 7), Escherichia coli DSM 498 and Pseudomonas aeruginosa DSM 50071 (both nutrient media TSB12 medium $=12 \mathrm{~g} \mathrm{l}^{-1}$ Difco tryptic soy broth, $10 \mathrm{~g} \mathrm{l}^{-1} \mathrm{NaCl}, \mathrm{pH}$ 7.2 in distilled water), as Gram-negative strains; and Bacillus subtilis DSM 347 and Staphylococcus lentus DSM 6672 (both nutrient media: TSB12) as representatives of Gram-positive bacteria. All strains were obtained from the German Collection of Microorganisms and Cell Cultures (DSMZ, Braunschweig, Germany). (ii) Five environmental strains that have been identified to be associated with macroalgae in previous studies (hereafter 'macroalga-associated set'): iia) three isolates were utilized which were obtained from the surface of Baltic Sea macroalgae Fucus vesiculosus and Delesseria sanguinea. The sampling procedure for isolating strains of bacteria associated with the macroalgae was performed according to Staufenberger et al. (2008). PCR amplifications of $16 \mathrm{~S}$ rRNA gene and subsequent sequencing were performed at the Institute for Clinical Molecular Biology (University Hospital SchleswigHolstein, Kiel, Germany). Phylogenetic analysis was performed as described by Heindl et al. (2010). 16S rDNA sequences of these strains (isolates AB423f, AB236d and AB251f) were deposited at NCBI under the accession numbers FR775437-FR775439. The isolates affiliated with $>99 \% 16 \mathrm{~S}$ rRNA gene sequence similarity to other macroalga-associated bacteria the Gram-positive Bacillus

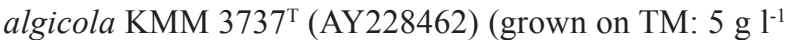
yeast extract, $1 \mathrm{~g} \mathrm{l}^{-1}$ peptone, $30 \mathrm{~g} \mathrm{l}^{-1}$ tropic marine sea salt in distilled water), Paenibacillus lautus JCM 9073 ${ }^{\mathrm{T}}$ (AB073188), and the Gram-negative Pseudomonas marincola $\mathrm{KMM} 3042^{\mathrm{T}}$ (AB301071) (grown on TSB12); iib) Two Gram-negative bacterial strains identified as 
macroalgal pathogens (by Sawabe et al. 1998, 2000), Algicola bacteriolytica ATCC $700679^{\mathrm{T}}$ ('red spot disease') and Pseudoalteromonas elyakovii ATCC $700519^{\mathrm{T}}$ ('spotwounded fronds'), originally isolated in Japan from diseased beds of Saccharina japonica (Areschoug) Lane et al. (formerly Laminaria japonica). Both were purchased from Institute Pasteur CIP (Paris, France), and grown cultivated on nutrient medium TM.

The bioactivity tests were modified according to Schneemann et al. (2010). Assay mixtures were prepared by transferring $10 \mu \mathrm{l}$ aliquots of methanolic solutions of extracts into a sterile 96-well microtiter plate and evaporating the solvent in a vacuum centrifuge. $200 \mu \mathrm{l}$ overnight cultures of each test strain were diluted to an optical density (OD) of 0.03 determined by spectrophotometry in the corresponding cultivation media (see above). Cultures of the standard set were incubated at $+36^{\circ} \mathrm{C}$ for $5 \mathrm{~h}$ under constant shaking at $200 \mathrm{rpm}$ except E. amylovora at $+28^{\circ} \mathrm{C}$. The macroalga-associated strains were cultivated at $+28^{\circ} \mathrm{C}$ for $20 \mathrm{~h}$; and the final OD was determined. We corrected the natural absorbance of the extract fractions by subtracting initial extract-only blank values from values obtained for treatments according to Lane et al. (2009). The tests were performed in 3 replicate treatments. By bacterial set a total of 240 tests were performed (16 macroalgal extracts $\mathrm{x} 5$ bacterial strains $\mathrm{x}$ triplicate). The resulting values were compared to those for a positive control (100 $\mu \mathrm{g} \mathrm{ml}^{-1}$ chloramphenicol) and respective negative controls wells: solvent ('no extract') and nutrient medium ('no extract, no solvent') on the same plate.

\section{RESULTS}

The antimicrobial assay showed that extracts of 14 from 16 macroalgal species ( $88 \%$ of the total) inhibited at least one of the tested organisms (Fig. 1a, b). Antimicrobial activity was demonstrated in members of the three phylogenetic divisions of macroalgae (Chlorophyta, Heterokontophyta and Rhodophyta, Table 2). Concerning the test organisms, Gram-positive bacteria and in

Table 2. Antibacterial activity and growth stimulation effect of the dichloromethane extracts of macroalga against a standard

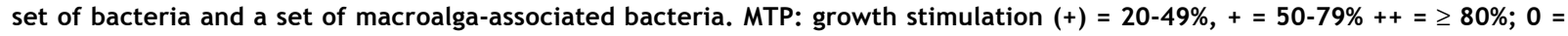
no biological activity; growth inhibition $(-)=20-49 \%,-=50-79 \%,--=\geq 80 \%$ / Actividad antibacteriana y de estimulación del crecimiento presentada por los diferentes extractos diclorometánicos de las macroalgas frente a un set estándar de cepas y uno de bacterias asociadas a macroalgas. La estimulación en el crecimiento fue designada con $(+)=20-49 \%,+=50-79 \%,++=\geq 80 \% ; 0=\sin$ actividad biológica; la inhibición del crecimiento bacteriano con $(-)=20-49 \%,-=50-79 \%,--=\geq 80 \%$

\begin{tabular}{lccccccccccc}
\hline & \multicolumn{1}{c}{ Standard Set } & \multicolumn{1}{c}{ Macroalga-associated Set } \\
Macroalga & \multicolumn{1}{c}{ Surface-associated } & Pathogenic \\
& B.s. & S.l. & E.a. & E.c. & P.a. & B.a. & P.l. & P.m. & A.b. & P.e. \\
\hline Chlorophyta & & & & & & & & & & \\
C. linum & 0 & $(+)$ & + & 0 & 0 & $(+)$ & $(+)$ & + & ++ & + \\
C. rupestris & $(-)$ & $(+)$ & $(+)$ & 0 & 0 & $(+)$ & 0 & + & + & $(+)$ \\
Heterokontophyta & & & & & & & & & & \\
F. serratus & - & 0 & $(+)$ & 0 & 0 & $(+)$ & 0 & + & 0 & 0 \\
F. vesiculosus & - & $(-)$ & + & 0 & 0 & $(+)$ & 0 & + & 0 & + \\
H. tomentosus & - & 0 & + & 0 & 0 & $(+)$ & $(+)$ & + & $(+)$ & $(+)$ \\
S. latissima & -- & 0 & $(+)$ & 0 & 0 & $(+)$ & 0 & + & $(+)$ & $(+)$ \\
Rhodophyta & & & & & & & & & & \\
B. hamifera & $(-)$ & $(-)$ & + & 0 & 0 & $(+)$ & $(+)$ & 0 & $(+)$ & 0 \\
C. corymbosum & - & 0 & + & 0 & 0 & $(+)$ & 0 & + & $(+)$ & $(+)$ \\
C. tenuicorne & $(-)$ & 0 & $(+)$ & 0 & - & + & 0 & + & 0 & $(+)$ \\
C. virgatum & - & 0 & $(+)$ & 0 & 0 & $(+)$ & 0 & + & ++ & $(+)$ \\
D. baillouviana & - & 0 & + & 0 & 0 & $(+)$ & $(+)$ & $(+)$ & ++ & ++ \\
D. sanguinea & 0 & 0 & $(+)$ & 0 & 0 & $(+)$ & 0 & + & ++ & ++ \\
D. contorta & $(-)$ & $(-)$ & + & 0 & 0 & $(+)$ & $(+)$ & + & ++ & + \\
$P$. elongata & $(-)$ & 0 & + & 0 & 0 & 0 & $(+)$ & + & + & 0 \\
$P$. nigra & -- & 0 & $(+)$ & 0 & 0 & $(+)$ & 0 & + & + & + \\
R. confervoides & - & $(-)$ & $(+)$ & 0 & 0 & 0 & $(+)$ & ++ & $(+)$ & $(+)$ \\
\hline & & & & & & & & & & & \\
\hline
\end{tabular}

Abbreviations / abreviaciones. Bs: Bacillus subtilis, Sl: Staphylococcus lentus, Ea: Erwinia amylovora, Ec: Escherichia coli, Pa: Pseudomonas aeruginosa, Ba: Bacillus algicola, Pl: Paenibacillus lautus, Pm: Pseudomonas marincola, Ab: Algicola bacteriolytica y Pe: Pseudoalteromonas elyakovii 

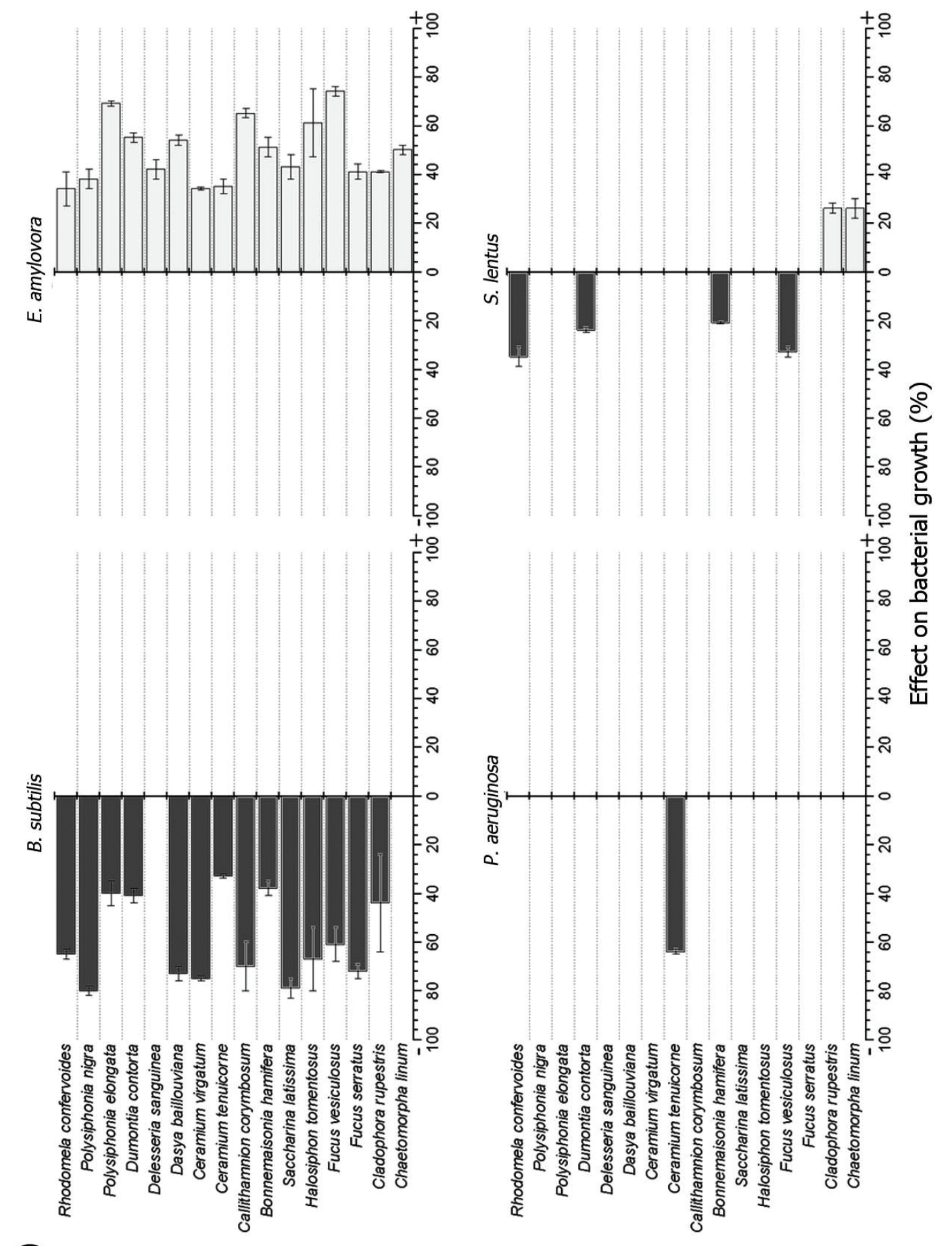

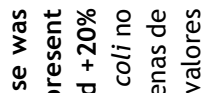

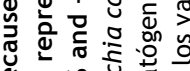

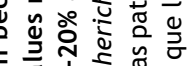

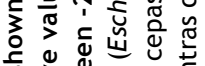

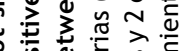

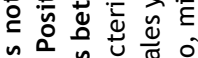

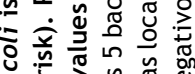

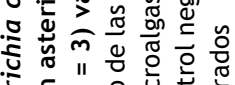

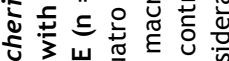

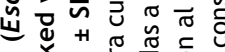

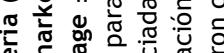

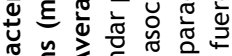

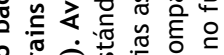

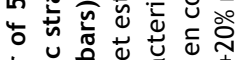

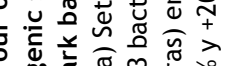

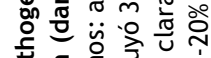

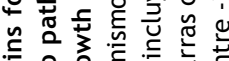

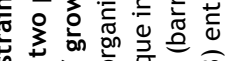

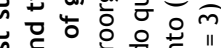

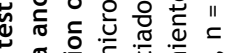

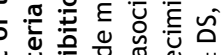

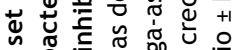

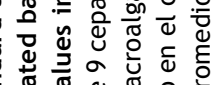

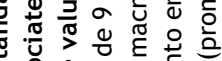

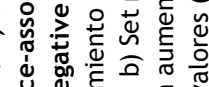

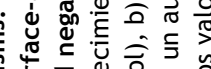

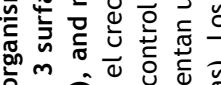

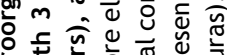

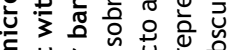

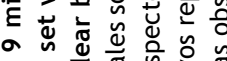

的过

돈

妿品

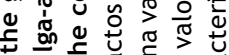

ᄃ。

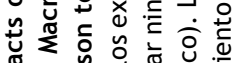

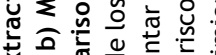

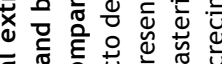
万ٓ

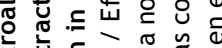
ब。 능 충

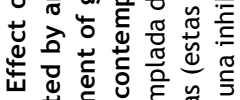
告

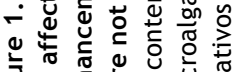

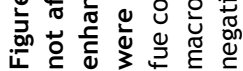




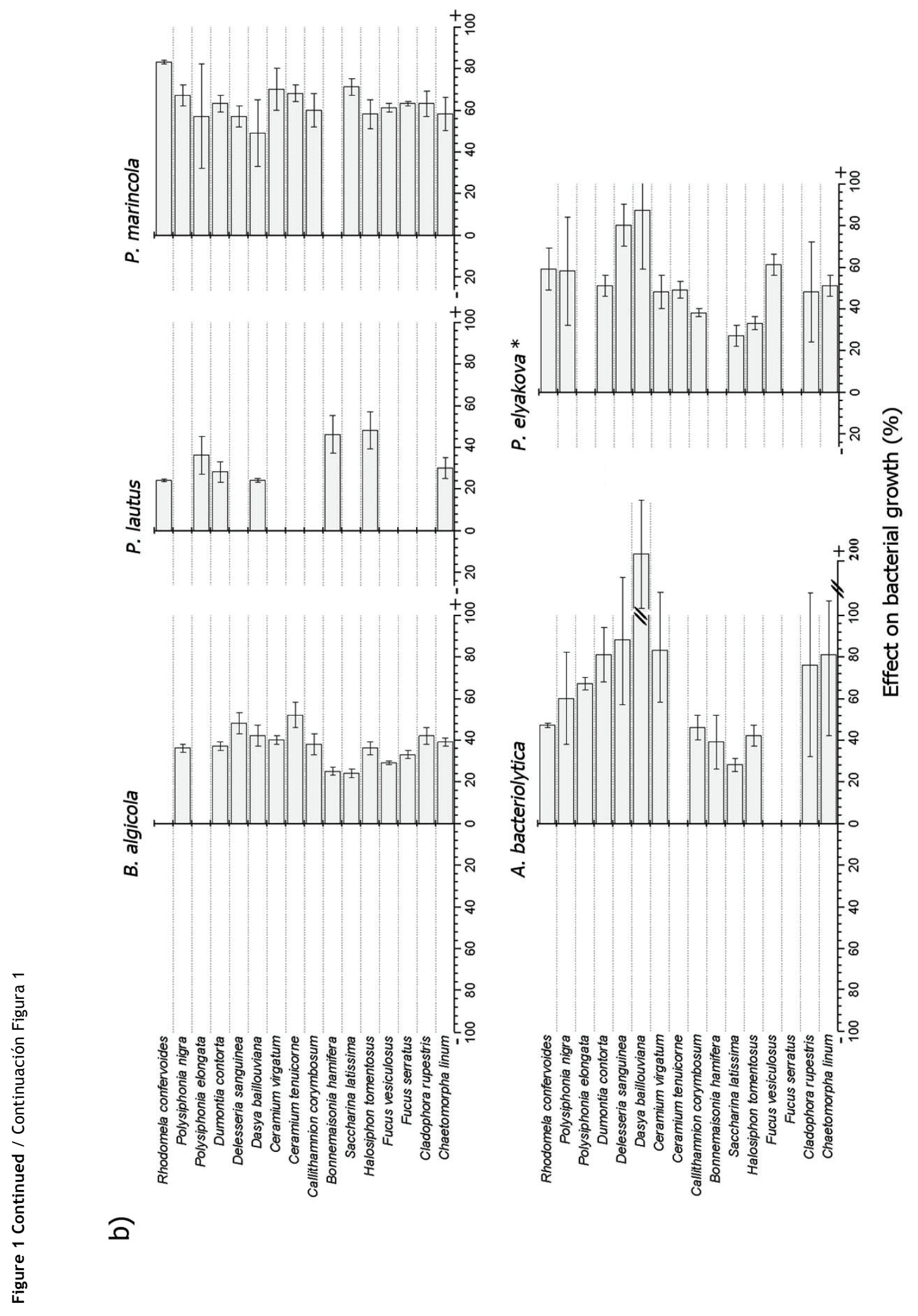


particular B. subtilis were most susceptible (Fig. 2). From the standard set E. amylovora and E. coli were not inhibited by any extract tested (Table 2, Fig. 2). Also, no extract presented inhibition of the algal pathogens or the other strains of the macroalga-associated set (Fig. 1b). The extracts of P. nigra and S. latissima presented the strongest inhibitory effect on the bacterial strains with around $80 \%$ growth inhibition of $B$. subtilis (Table 2, Fig. 1a). No particular trend in the biological activity was observed by taxonomical macroalgal division (Fig. 3). Although growth inhibitory effects were generally weak (only against 3 bacterial strains and less than $80 \%$ of growth inhibition, Fig. 1a), there was a higher proportion of macroalgal species which inhibited the standard test strains $(23.8 \%$ of the total tests performed) compared to species associated with macroalga ( $0 \%$, Fig. 2). Only $12 \%$ of the algal species did not present any antibiotic activity (Fig. 1, 3).
Interestingly, the present study revealed significant growth stimulation of macroalga-associated bacteria (Table 2, Fig. 1b). The totality of the extracts stimulated the growth of at least two of the tested bacteria (Fig. 3). While growth stimulation of the standard set of bacteria was rare $(22.5 \%$ of the total tests) - with the exception of plant pathogen E. amylovora and just two cases of $S$. lentus (Fig. 2) - it was common among bacteria associated with macroalgae (77.5\%), especially $B$. algicola and $P$. marincola. Quite interestingly, also growth of the macroalgal pathogens A. bacteriolytica and P. elyakovii was stimulated by most of the macroalgal extracts (both $81.3 \%$ of the total), and surprisingly none of the macroalgal extracts inhibited these two strains (Figs. 1,2). The extract of D. baillouviana presented the strongest stimulatory growth effects on the bacterial strains with around $200 \%$ growth stimulation of $A$. bacteriolytica (Fig. 1b).

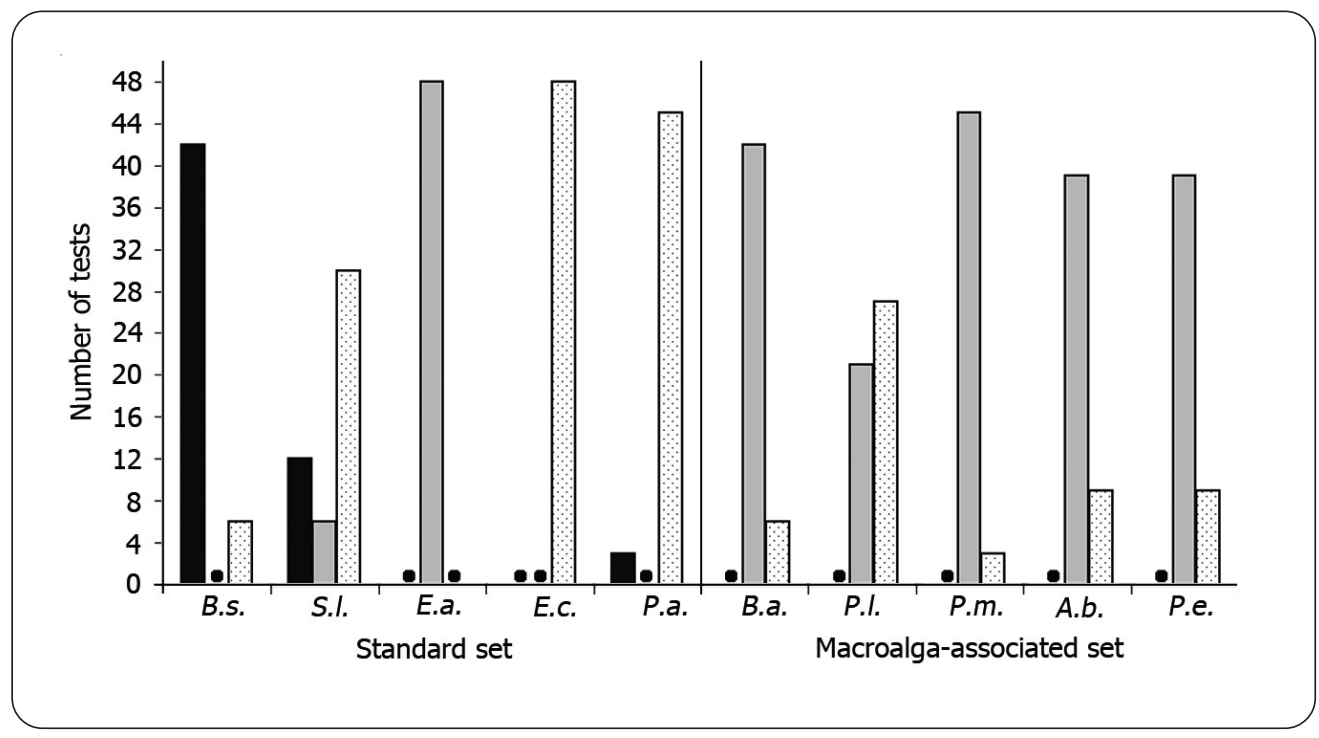

Figure 2. Summary by bacterial strain of the effect on the growth performed with the macroalgal extracts. To the left, standard set and to the right, macroalga-associated set. The bars represent enhancement of growth (grey), inhibition of growth (dark stripes) and no significant variation of growth (points) in comparison to negative controls. Absence of inhibitory/stimulatory activity is designated with a black dot. A total of $\mathbf{4 8}$ tests were performed for each strain. See the list of abbreviation in Table 2 / Resumen del efecto en el crecimiento bacteriano según microorganismos producido por los extractos macroalgales investigados. A la izquierda, set estándar y a la derecha, set macroalga-asociado. Las barras representan estimulación del crecimiento (gris), inhibición del crecimiento (negro) y sin efecto significativo (barras con puntos) en comparación a los controles negativos. La ausencia de actividad biológica fue designada con un punto negro. Un total de 48 pruebas fue realizado para cada cepa. Ver lista de abreviaturas en Tabla 2 


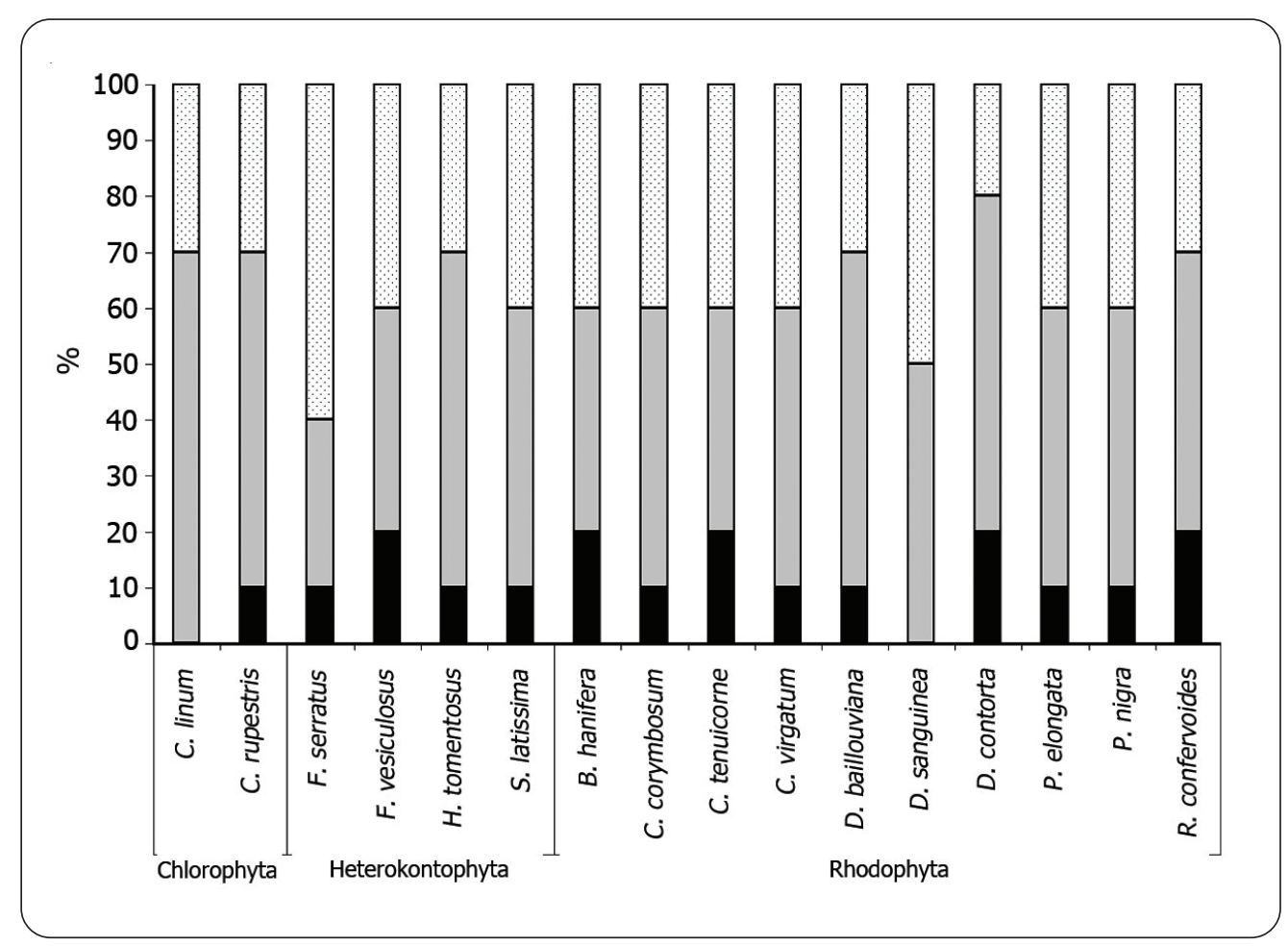

Figure 3. Proportion of growth inhibition (dark stripes), enhancement of growth (grey), and no significant variation of growth (points) of microorganisms exposed to extracts of different macroalgal species / Proporción de la inhibición del crecimiento (barras negras), estimulación del crecimiento (barras grises), y la ausencia de una variación significativa (barras con puntos) en el crecimiento de microorganismos expuestos a los diferentes extractos macroalgales

\section{Discussion}

In the majority of prior studies, bacterial growth inhibiting activities of different macroalgal extracts were investigated on human pathogens or standard terrestrial strains (Dubber \& Harder 2008). In the present study, we investigated the different effects macroalgal extracts can display over the growth of bacteria especially by testing ecologically relevant microorganisms. Hughes \& Fenical (2011) suggested recently that antibacterial activity can only be evaluated in the context of the bacteria strains that are selected. We demonstrated that one macroalgal extract can display different effects on growth of microorganisms especially by testing macroalgaassociated bacteria in comparison with a standard set of bacteria.

In the present study, $88 \%$ of the macroalgae displayed antibacterial activity against at least one of the test strains. The antibiotic effect was observed only against 3 bacterial strains from the standard set and less than $80 \%$ of inhibition. Extracts of some macroalgal species usually associated with high antimicrobial activity as Rhodomela confervoides (Glombitza 1969) and Bonnemaisonia hamifera (Nylund et al. 2005, Persson et al. 2011; Fig. 1a) were active too. $B$. subtilis from the standard set was the most susceptible to the macroalgal extracts (Fig. 2) in accordance with other studies on macroalgae (FreilePelegrin \& Morales 2004, Dubber \& Harder 2008, SánchezSaavedra et al. 2010).

Just a few studies have investigated the biological activities of macroalgal extracts of the German coasts, and most of them have used standard bacteria. For example, Roos (1957) investigated 27 species of macroalgae of the Kiel Fjord, and tested them against standard strains including Staphylococcus aureus, B. subtilis and E. coli. Most species (82\%) were active 
against at least one of the tested microorganisms. As in the present study, Roos also found antibacterial activity in $F$. serratus, $F$. vesiculosus, $P$. elongata, $R$. confervoides (as R. subfusca), and S. latissima. Later, Glombitza (1969) confirmed some of these results during a study with 41 macroalgae from the coastal zone of the Helgoland Island in the German North Sea including C. rupestris, $D$. contorta (as D. incrassata), S. latissima, F. vesiculosus, and $R$. confervoides. The author also used standard bacteria in the tests (i.e., Bacillus cereus, B. subtilis, E. coli, Proteus vulgaris, Sarcina lutea, and S. aureus). From the same German island, Duber \& Harder (2008) tested macroalgal extracts of Ceramium rubrum, Mastocarpus stellatus and Laminaria digitata against 7 fish pathogenic bacteria and 12 bacteria from marine sediments. Extracts of those 3 macroalgae presented high activity against growth of different strains. In another study, extracts of 4 German North Sea macroalgae $(C$. rubrum, Hypoglossum hypoglossoides, S. latissima, and Plocamium cartilagineum) were tested against 5 fish pathogenic strains, inhibiting all the macroalgae at least one bacterial strain, from which $S$. latissima was active only against Vibrio anguillarum (Bansemir et al. 2006).

Although these studies clearly showed that macroalgae commonly contain active metabolites with antibacterial properties, it is not known whether the metabolites have an active role within the ecological interactions with their natural enemies (Jormalainen \& Honkanen 2008), and/or symbionts. Important variations in the effect of different macroalgal extracts on different marine fouling microorganisms have been shown by Hellio et al. (2000, 2001). In a study in the Caribbean Sea, the marine bacterial strains (including $P$. elyakovii) selected were most sensitive to extracts of Sargassum polyceratium compared to a standard bacterial strains, suggesting that defence strategies of this brown alga are specific (Thabard et al. 2011). Such targeted defence strategies have been described for some algal species before (see Paul \& Puglisi 2004).

Different crude extracts tested in the present study have significantly stimulated the growth of bacteria, especially ecologically relevant strains (both surface associated and pathogenic strains, Table 2). One of the extract, of the introduced species $D$. baillouviana, presented the strongest stimulatory effects on the bacterial strains with $\sim 200 \%$ growth stimulation of the pathogen A. bacteriolytica (Fig. 1b). Although several studies have shown stimulation of bacterial growth by algae, unfortunately, they have been based generally on exudates rather than extracts, and usually of phytoplanktonic sources (see Bell et al. 1974, Larsson \& Hagström 1979, Brock \& Clyne 1984, Murray et al. 1986, Coveney \& Wetzel 1989). Algal exudates, unknown or partially specified, have been shown to significantly affect the community structure of bacteria in biofilms and in the pelagic zone near the macroalgae (see Dobretsov et al. 2006, Lam \& Harder 2007, Lachnit et al. 2010, Persson et al. 2011, Saha et al. 2011, Sneed \& Pohnert 2011a, b). It is well known that macroalgae release large amounts of organic carbon into the surrounding environment, providing nutrients for microorganisms (Koop et al. 1982, Wada et al. 2007). Heterotrophic bacteria can directly utilize products excreted by algae as growth substrates (Larsson and Hagström 1979, Brock \& Clyne 1984). Excreted compounds may also trigger chemotactic behaviour and stimulate growth (Goecke et al. 2010). These compounds are quite selective in their stimulation of bacteria, because different bacteria differ considerably in their ability to respond to these products (Bell et al. 1974). The strainspecific preferences for certain substrates and strain specific pro- or antifouling activities of algal metabolites play an important role in establishing ecological associations (Wahl et al. 2010). It has been suggested that chemical defences may affect marine communities by promoting some microbes on algal surfaces while deterring others (Lane \& Kubanek 2008). However, after more than 20 yrs of research on this topic, there is still no experimental evidence demonstrating if or how host organisms selectively attract and harbour their epibionts (Harder 2009); especially because the studies focussed on inhibitory activities of extracts or metabolites and rarely were concerned with stimulatory effects on growth of the microorganisms.

The bacterial growth stimulatory effect may have different explanations. As mentioned recently, those organic extracts and compounds may rather resemble dead algal material available for microbial degradation (Bengtsson et al. 2011). Nevertheless, the possibility of the presence of certain algal substances that specifically stimulate a selected array of species or even strains has also been suggested recently (see Sneed \& Pohnert 2011b).

In the present study, we tested activities of macroalgal extracts against two macroalgal pathogens: $A$. bacteriolytica (formerly Pseudoalteromonas bacteriolytica) and P. elyakovii. All studied macroalgae revealed no inhibitory activities against these pathogens; on the contrary, growth stimulatory activities were in 
general displayed (Fig. 1b). The extract of S. latissima, which was the only studied brown macroalga that belong to Laminariales, stimulated growth of both macroalgal pathogens (but $<30 \%$ ). Members of this genus were originally affected by those pathogens (Sawabe et al. 1998, 2000). Recently, in tropical environments, extensive investigations of different macroalgal extracts have shown high biological activity against $A$. bacteriolytica (Engel et al. 2006, Puglisi et al. 2007, Lane et al. 2010). This indicates highly variable amounts and different composition of active compounds, probably depending on the biotic and abiotic pressures onto the macroalgae. It is accepted that chemical defences are elaborated to a greater extent and are more important in tropical than temperate or cold areas as in the German coast (see Pereira $\&$ da Gama 2008). Unfortunately, with the exception of one study using causative agents of the macroalgal iceice disease (by Vairappan et al. 2010) and P. elyakovii (by Thabard et al. 2011), bioactivity tests of algal extracts or compounds against other known bacterial pathogens of macroalgae were rarely performed.

As recommended by Engel et al. (2006) caution must be exercised about drawing ecological conclusions of the role of secondary metabolites on the observed biological activity. The concentration used in our assays followed standard procedure (see Bansemir et al. 2006, MuñozOchoa et al. 2010, Sánchez-Saavedra et al. 2010, VillarrealGómez et al. 2010), and crude extracts are usually complex mixtures of compounds. Therefore it is unknown which substances at which concentration exhibited the bioactivity in nature (Persson et al. 2011). Despite the inconveniences using crude extracts of whole organism already mentioned by several authors (see Paul et al. 2006, Lane et al. 2009, Nylund et al. 2010), there is no doubt that such experiments provide insights into the potential interactions mediated by algal metabolites, especially by using environmental test strains. We confirmed that macroalgal extracts exert effects of growth inhibition and stimulation according to the nature of the bacterial strains selected. We demonstrated that macroalgal extracts have growth stimulant effects on macroalga-associated bacteria including algal pathogens.

\section{ACKNOWLEDGMENTS}

This study was financed by the DAAD (German Academic Exchange Service), the CONICYT (Comisión Nacional de Investigación Científica y Tecnológica, Chile), and the Ministry of Science, Economic Affairs and Transport of the State of Schleswig-Holstein (Germany) within the frame of the 'Future Program of Economy', which is supported by the European fund for regional development (EFRE). We are grateful to Dr. Herwig Heindl and Tim Staufenberger for helping in the sampling process, and Arlette Erhard for the kind helps in bioassay methodology.

\section{LITERATURE CITED}

Arunkumar K, SR Sivakumar \& R Rengasamy. 2010. Review on bioactive potential in seaweeds (marine macroalgae): a special emphasis on bioactivity of seaweeds against plant pathogens. Asian Journal of Plant Sciences 9: 227-240.

Bansemir A, M Blume, S Schröder \& U Lindequist. 2006. Screening of cultivated seaweeds for antibacterial activity against fish pathogenic bacteria. Aquaculture 252: 79-84.

Bell WH, JM Lang \& R Mitchell. 1974. Selective stimulation of marine bacteria by algal extracellular products. Limnology and Oceanography 19: 833-839.

Bengtsson MM, K Sjotun, JE Storesund \& L Ovreas. 2011. Utilization of kelp-derived carbon sources by kelp surfaceassociated bacteria. Aquatic Microbial Ecology 62: 191-199.

Brock TD \& J Clyne. 1984. Significance of algal excretory products for growth of epilimnetic bacteria. Applied and Environmental Microbiology 47: 731-734.

Coveney MF \& RG Wetzel. 1989. Bacterial metabolism of algal extracellular carbon. Hydrobiologia 173: 141-149.

Dobretsov S, HU Dahms, T Harder \& PY Qian. 2006. Allelochemical defense against epibiosis in the macroalga Caulerpa racemosa var. turbinata. Marine Ecology Progress Series 318: 165-175.

Dubber D \& T Harder. 2008. Extracts of Ceramium rubrum, Mastocarpus stellatus and Laminaria digitata inhibit growth of marine and fish pathogenic bacteria at ecologically realistic concentrations. Aquaculture 274: 196-200.

Egan S, T Thomas, C Holmstrom \& S Kjelleberg. 2000. Phylogenetic relationship and antifouling activity of bacterial epiphytes from the marine alga Ulva lactuca. Environmental Microbiology 2: 343-347.

Engel S, MP Puglisi, PR Jensen \& W Fenical. 2006. Antimicrobial activities of extracts from tropical Atlantic marine plants against marine pathogens and saprophytes. Marine Biology 149: 991-1002.

Freile-Pelegrin Y \& JL Morales. 2004. Antibacterial activity in marine algae from the coast of Yucatan, Mexico. Botanica Marina 47: 140-146.

Goecke F, A Labes, J Wiese \& JF Imhoff. 2010. Chemical interactions between marine macroalgae and bacteria. Marine Ecology Progress Series 409: 267-300.

Glombitza KW. 1969. Antibakterielle inhaltsstoffe in algen. Helgolander Wissenschaftliche Meeresuntersuchungen 19: 376-384. 
Guiry MD \& GM Guiry. 2011. AlgaeBase. World-wide electronic publication, National University of Ireland, Galway. [on line] $<$ http://www.algaebase.org $>$.

Harder T. 2009. Marine epibiosis: concepts, ecological consequences and host defence. In: Flemming HC, PS Murthy, R Venkatesan \& K Cooksey (eds). Marine and industrial biofouling, pp. 219-231. Springer, Berlin.

Heindl H, J Wiese, V Thiel \& JF Imhoff. 2010. Phylogenetic diversity and antimicrobial activities of bryozoanassociated bacteria isolated from Mediterranean and Baltic Sea habitats. Systematic and Applied Microbiology 33: 94-104.

Hellio C, G Bremer, AM Pons, Y Le Gal \& N Bourgougnon. 2000. Inhibition of the development of microorganisms (bacteria and fungi) by extracts of marine algae from Brittany (France). Applied Microbial Biotechnology 54: 543-549.

Hellio C, D De La Broise, L Dufossé, Y Le Gal \& N Bourgougnon. 2001. Inhibition of marine bacteria by extracts of macroalgae: Potential use for environmentally friendly antifouling paints. Marine Environmental Research 52: 231-247.

Hellio C, JP Marechal, B Véron, G Bremer, AS Clare \& Y Le Gal. 2004. Seasonal variation of antifouling activities of marine algae from the Brittany Coast, France. Marine Biotechnology 6: 67-82.

Hughes CC \& W Fenical. 2011. Antibacterials from the sea. Chemistry a European Journal 16: 12512-12525.

Jormalainen V \& T Honkanen. 2008. Macroalgal chemical defenses and their roles in structuring temperate marine communities. In: Amsler CD (ed). Algal chemical ecology, pp. 57-89. Springer-Verlag, Berlin Heidelberg.

Kanagasabhapathy M, H Sasaki, S Haldar, S Yamasaki \& S Nagata. 2006. Antibacterial activities of marine epibiotic bacteria isolated from brown algae of Japan. Annals of Microbiology 56: 167-173.

Koop K, RC Newell \& MI Lucas. 1982. Microbial regeneration of nutrients from the decomposition of macrophyte debris on the shore. Marine Ecology Progress Series 9: 91-96.

Lachnit T, M Blümel, JF Imhoff \& M Wahl. 2009. Specific epibacterial communities on macroalgae: phylogeny matters more than habitat. Aquatic Biology 5: 181-186.

Lachnit T, M Wahl \& T Harder. 2010. Isolated thallus-associated compounds from the macroalga Fucus vesiculosus mediate bacterial surface colonization in the field similar to that on the natural alga. Biofouling 26: 247-255.

Lam C \& T Harder. 2007. Marine macroalgae affect abundance and community richness of bacterioplankton in close proximity. Journal of Phycology 43: 874-881.

Lane AL \& J Kubanek. 2008. Secondary metabolite defenses against pathogens and biofoulers. In: Amsler CD (ed). Algal chemical ecology, pp. 229-243. Springer-Verlag, Berlin Heidelberg.
Lane AL, L Nyadong, AS Galhena, TL Shearer, EP Stout, RM Parry, M Kwasnik, MD Wang, ME Hay, FM Fernandez \& J Kubanek. 2009. Desorption electrospray ionization mass spectrometry reveals surface-mediated antifungal chemical defence of a tropical seaweed. Proceedings of the National Academy of Sciences 106: 73147319.

Lane AL, L Mular, EJ Drenkard, TL Shearer, S Engel, S Fredericq, CR Fairchild, J Prudhomme, K Le Roch, ME Hay, W Aalbersberg \& J Kubanek. 2010. Ecological leads for natural product discovery: novel sesquiterpene hydroquinones from the red macroalga Peyssonnelia sp. Tetrahedron 66: 455-461.

Larsson U \& A Hagström. 1979. Phytoplankton exudates as an energy source for the growth of pelagic bacteria. Marine Biology 52: 199-206.

Magallanes C, C Córdova \& R Orozco. 2003. Actividad antibacteriana de extractos etanólicos de macroalgas marinas de la costa central del Perú. Revista Peruana de Biología 10: 125-132.

Maggs CA \& MH Hommersand. 1993. Seaweeds of the British Isles. Vol.1. Rhodophyta. Part 3a Ceramiales, 444 pp. The Natural History Museum, London.

Maschek JA \& BJ Baker. 2008. The chemistry of algal secondary metabolism. In: Amsler CD (ed). Algal chemical ecology, pp. 1-24. Springer-Verlag, Berlin.

Muñoz-Ochoa M, JI Murillo-Álvarez, LA ZermeñoCervantes, S Martínez-Díaz, R Rodríguez-Riosmena. 2010. Screening of extracts of algae from Baja California Sur, Mexico as reversers of the antibiotic resistance of some pathogenic bacteria. European Review for Medical and Pharmacological Sciences 14: 739-747.

Murray RE, KE Cooksey \& JC Priscu. 1986. Stimulation of bacterial DNA synthesis by algal exudates in attached algalbacterial consortia. Applied and Environmental Microbiology 52: 1177-1182.

Nylund GM, G Cervin, M Hermansson \& H Pavia. 2005. Chemical inhibition of bacterial colonization by the red alga Bonnemaisonia hamifera. Marine Ecology Progress Series 302: 27-36.

Nylund GM, F Persson, M Lindegarth, G Cervin, M Hermansson \& H Pavia. 2010. The red alga Bonnemaisonia asparagoides regulates epiphytic bacterial abundance and community composition by chemical defence. FEMS Microbiology Ecology 71: 84-93.

Pankow H. 1971. Algenflora der Ostsee. 1. Benthos, 419 pp. VEB Gustav Fischer, Jena.

Paul NA, R de Nys \& PD Steinberg. 2006. Chemical defence against bacteria in the red alga Asparagopsis armata: Linking structure with function. Marine Ecology Progress Series 306: 87-101.

Paul VJ \& MP Puglisi. 2004. Chemical mediation of interactions among marine organisms. Natural Products Reports 21: 189-209. 
Pereira RC \& BAP da Gama. 2008. Macroalgal chemical defenses and their roles in structuring tropical marine communities. In: Amsler CD (ed). Algal chemical ecology, pp. 25-55. Springer-Verlag, Berlin.

Persson F, R Svensson, GM Nylund, NJ Fredriksson, H Pavia \& M Hermansson. 2011. Ecological role of a secondary metabolite for a colonizing bacterial community. Biofouling 27: 579-588.

Puglisi MP, S Engel, PR Jensen \& W Fenical. 2007. Antimicrobial activities of extracts from Indo-Pacific marine plants against marine pathogens and saprophytes. Marine Biology 150: 531-540.

Roos H. 1957. Untersuchungen über das vorkommen antimikrobieller substancen in meeresalgen. Kieler Meeresforschung 13: 41-58.

Saha M, M Rempt, K Grosser, G Pohnert \& F Weinberger. 2011. Surface-associated fucoxanthin mediates settlement of bacterial epiphytes on the rockweed Fucus vesiculosus. Biofouling 27: 423-433.

Sánchez-Saavedra MP, A Licea-Navarro \& J BernáldezSarabia. 2010. Evaluation of the antibacterial activity of different species of phytoplankton. Revista de Biología Marina y Oceanografía 45: 531-536.

Sandsdalen E, T Haug, K Stensvag \& OB Styrvold. 2003. The antibacterial effect of a polyhydroxylated fucophlorethol from the marine brown alga, Fucus vesiculosus. World Journal of Microbiology and Biotechnology 19: 777-782.

Schneemann I, K Nagel, I Kajahn, A Labes, J Wiese \& JF Imhoff. 2010. Comprehensive investigation of marine Actinobacteria associated with the sponge Halichondria panicea. Applied and Environmental Microbiology 76: 3702-3714.

Sneed JM \& G Pohnert. 2011a. The green alga Dictyosphaeria ocellata and its organic extracts alter natural bacterial biofilm communities. Biofouling 27: 347-356.
Sneed JM \& G Pohnert. 2011b. The green macroalga Dictyosphaeria ocellata influences the structure of the bacterioplankton community through differential effects on individual bacterial phylotypes. FEMS Microbiology Ecology 75: 242-254.

Sridhar KR \& N Vidyavathi. 1991. Antimicrobial activity of seaweeds. Acta Hydrochimica et Hydrobiologica 5: 455-496.

Staufenberger T, V Thiel, J Wiese \& JF Imhoff. 2008. Phylogenetic analysis of bacteria associated with Laminaria saccharina. FEMS Microbiology Ecology 64: 65-77.

Thabard M, O Gros, C Hellio \& JP Maréchal. 2011. Sargassum polyceratium (Phaeophyceae, Fucaceae) surface molecule activity towards fouling organisms and embryogenic development of benthic species. Botanica Marina 54: 147-157.

Vairappan CS, SP Anangdan, KL Tan \& S Matsunaga. 2010. Role of secondary metabolites as defence chemicals against ice-ice disease bacteria in biofouler at carrageenophyte farms. Journal of Applied Phycology 22: 305-311.

Villarreal-Gómez LJ, IE Soria-Mercado, G Guerra-Rivas \& NE Ayala. 2010. Actividad anticancerígena y antibacteriana de macroalgas y bacterias asociadas a su superficie. Revista de Biología Marina y Oceanografía 45: 267-275

Wada S, MN Aoki, Y Tsuchida, T Sato, H Shinagawa \& T Hama. 2007. Quantitative and qualitative analyses of dissolved organic matter released from Ecklonia cava Kjellman, in Oura bay, Shimoda, Izu Peninsula, Japan. Journal of Experimental Marine Biology and Ecology 349: 344-358.

Wahl M, L Shahnaz, S Dobretsov, M Saha, F Symanowski, K David, T Lachnit, M Vasel \& F Weinberger. 2010. Ecology of antifouling resistance in the bladder wrack Fucus vesiculosus: patterns of microfouling and antimicrobial protection. Marine Ecology Progress Series 411: 33-48.

Received 31 August 2011 and accepted 30 January 2012 